\title{
NANOPARTICLES-PHENOLICS AS ANTI SALMONELLA TYPHIMURIUM
}

\author{
MAHMOUD AMMAR MOHAMED AMMAR ${ }^{1}$; ASMAA MOHAMMED HENETER ${ }^{2}$; \\ TALAAT SAYED ALY EL-KHATEIB ${ }^{3}$; ASHRAF MOHAMED \\ ABD EL-MALEK ${ }^{4}$ AND AHMAD MOHAMED AHMAD ABO MARKEB ${ }^{5}$ \\ ${ }^{1 \& 2}$ Agriculture Research Center -Animal Health Research Institute-Assuit Regional Lab., Egypt. \\ Email: mahmoud2014eg@yahoo.com; asmaheneter@gmail.com \\ ${ }^{3 \& 4}$ Faculty of Veterinary Medicine, Assuit University, Egypt. \\ Email: Talaatkhateib52@gmail.com; Ashraf_702001@yahoo.com \\ ${ }^{5}$ Faculty of Science, Assuit University, Egypt, Email: a_markeb@aun.edu.eg
}

Received: 3 August 2021; Accepted: 5 September 2021

\begin{abstract}
The present study was designed to evaluate the activities of six phenolic compounds. Their activities against the potential foodborne pathogen $S$. Typhimurium were assessed using macro dilution and spectrophotometric methods. Their activities were in the order of thymol > benzoic acid > coumarin > cinnamic acid $>$ curcumine $>$ gallic acid. Thymol was bactericidal at a concentration of $0.08 \mathrm{mg} / \mathrm{ml}$. With exception of curcumine, other phenolics revealed bactericidal effect in concentration varied from 1.25 to $10.00 \mathrm{mg} / \mathrm{ml}$. Minimum inhibitory concentration (MICs) values by spectrophotometric method were significantly different compared to visual method in some antimicrobial assays. Coating fish with solutions of thymol or chitosan nanoparticle (CNPs) significantly reduced salmonella population. The nanostructured thymol CNPs capsule controlled the release of thymol and the effect in fish matrix continued significant during cold storage without adverse effect on $\mathrm{pH}$ value. The tested phenolics have the potential to be used in development of food coating technology. Also the formulated nanocapsule is promising in controlling the hazard of $S$. Typhimurium in fish.
\end{abstract}

Keywords: Phenolics — thymol- Salmonella - Nanoparticles encapsulation.

\section{INTRODUCTION}

Salmonellosis is a very common enteric infection which may be mild or severe life-threatening disease. The causative agent is Gram-negative bacterium belonging to the family Enterobacteriaceae.

Corresponding author: Mahmoud Ammar Mohamed Ammar E-mail address: mahmoud2014eg@yahoo.com Present address: Agriculture Research Center Animal Health Research Institute-Assuit Regional Lab., Egypt.
The major cause of human salmonellosis outbreaks in the United States and Europe is Salmonella enterica serovar Enteritidis (Gould et al., 2013 and Collard et al., 2008). The main routes of transmission are live stocks, consumption of contaminated food and human-to-human via the fecal-oral route (Tarabees et al., 2017 and Kassem et al., 2016).

Food safety is a shared goal for both consumers and food producers. Contamination with salmonella represents a threat to public health. It is one of the top 4 germs in the world with more 
hospitalizations and deaths than any other bacteria found in food (EFSA and ECDC, 2018). It has been repeatedly detected in a diverse variety of food products. Studies on food samples from street venders, butchers shops, retail markets and slaughterhouses (Ahmed and Shimamoto, 2014 and Ahmed et al., 2014) as well as seafood (Bakr et al., 2013) revealed salmonella. Besides, $68 \%$ of detected Salmonella enterica isolates showed multidrug resistance phenotypes which are of great health significance (Ahmed et al., 2014).

Great efforts of research work have been directed toward the prevention of food borne diseases. Prevention demands critical antimicrobial strategies to decontaminate the food through its procession from farm till consumption (Jayasena and Jo, 2013). Researchers have been studied the inhibitory effect of extracts of spices (Ravichandran et al., 2011 However, little is known about the potential use of the phenolic compounds which could be exploited by the food processors for use as natural preservatives.

Phenolics are bioactive substances occurring widely in food plants. The phenolic fraction of plant extracts has been linked to their antimicrobial activity as natural and safer alternatives to chemicals in food systems with the advantage of low cost. Their application as food preservatives on wide scale still faces limitations due to their high volatile character and sensitivity to oxygen (Hyldgaard et al., 2012). Encapsulation of bioactive materials was reported to enhance their solubility and stability (Ghaderi-Ghahfarokhi et al., 2016). In this respect, nanotechnology serves to manipulate matter at the nanometre scale, create and assemble substances at a molecular level with new and interesting properties. This study aims to evaluate the activity of some phenolics against Salmonella Typhimurium, and investigate the effect of nanoencapsulation of phenolic on its antibacterial efficiency in fish matrix.

\section{MATERIALS AND METHODS}

\section{Bacterial strains}

Salmonella Typhimurium- Reference strain (NCTC12023) was obtained from Animal Health Research Institute, Assiut, Egypt. The culture was activated by cultivation from the stock culture into Brain Heart Infusion Broth (BHIB), and incubated overnight at $35^{\circ} \mathrm{C}$. Then subcultured by seeding growth to Xylose Lysine Deoxycholate agar (XLD agar, Himedia M031) and incubated $24 \mathrm{~h}$ at $35^{\circ} \mathrm{C}$. Typical colonies were picked on Brain Heart Infusion Agar (BHIA) slants and incubated for $24 \mathrm{~h}$ at $35^{\circ} \mathrm{C}$ as recommended by (Hsiao and Siebert, 1999).

\section{Preparation of inoculum}

Inoculums were prepared by seeding pure growth from the slants to XLD agar and incubated $24 \mathrm{~h}$ at $35^{\circ} \mathrm{C}$ then four typical colonies were transferred to $10 \mathrm{ml}$ BHIB and incubated for $18 \mathrm{~h}$ at $35^{\circ} \mathrm{C}$. The optical density $\left(\mathrm{OD}_{625}\right)$ of the growth suspension was measured at $625 \mathrm{~nm}$ using spectrophotometer (Stat-fax 2100 spectrophotometer) where non-inoculated broth acts as blank. The bacterial suspension was diluted to approximate level $\mathrm{OD}_{625}$ of $(0.08-012)$ that corresponds to $0.5 \mathrm{McF}$ arland and confirmed by counting the number of cfu / $\mathrm{ml}$ on agar plates (McFarland 1907; Natta et al., 2008).

\section{Evaluation of antimicrobial activities of phenolic compounds:}

\subsection{Determination of minimum inhibitory concentrations (MICs) against $S$. Typhimurium by macro (visual) and micro (spectrophotometric) dilution methods:}

Thymol, gallic acid, curcumine, coumarin, cinnamic acid, benzoic acid were obtained from El-Goumhouria Company for Trading 
Chemicals, Cairo, Egypt. All are ( $\geq 98.5 \%$ purity) according to manufacture label. Separate stock solutions $(10 \mathrm{mg} / \mathrm{ml})$ each of phenolic compounds were prepared in BHIB with dimethylsulfoxide (DMSO, Sigma-Aldrich Co., USA) at 5\% initial concentration as a solvent. Then, double fold serial dilutions (DFSD) of these compounds were prepared separately from stock solutions using BHIB to obtain concentrations of $0.004,0.009,0.019$, $0.039,0.078,0.156,0.312,0.625,1.250$, $2.500,5.000$ and $10.000 \mathrm{mg} / \mathrm{ml}$. MICs were determined in tubes and in sterile 96 well flat bottomed polystyrene microtitre plates as recommended with the Clinical and Laboratory Standards Institute (CLSI, 2012). In spectrophotometric method, each well was inoculated with $5 \mu$ l of target bacterial suspension (calculated $1.5 \times 10^{8}$ $\mathrm{cfu} / \mathrm{ml}$ ) and $300 \mu \mathrm{l}$ of fresh prepared DFSD of phenolic compound under investigation. BHIB alone was included to detect any cross contamination during shaking or handling. The phenolic compound dilutions without bacteria were used as a blank. Wells contains bacteria without phenolic compound were used as positive control.

To determine MICs using visual method, the same dilutions and inoculum concentration of target bacteria were used but wells were replaced by Wassermann tubes. After gentile mixing, the inoculated tubes and microtitre plate were incubated (mostly without agitation) at $35^{\circ} \mathrm{C}$ for $24 \mathrm{~h}$. Optical density readings of test microplates were obtained using a microplate reader while tubes were examined by naked eye. The experiments were performed in triplicates.

In the spectrophotometric method, the lowest concentration of phenolic compound with $\mathrm{OD}_{600}$ reading equal to blank $\mathrm{OD}_{600}$ was considered the MIC (Pacheco-Ordaz et al., 2017) while in visual method, the lowest concentration of clear tubes (no turbidity) was recorded as MIC (CLSI, 2012). The growth inhibition percent (GI \%) was calculated using the equation recommended by (Liu et al., 2017) where :
$\mathrm{GI}(\%)=\mathrm{OD}_{\text {bacteria }}-(\mathrm{OD}$ (bacteria+ antimicrobial $)-$ $\mathrm{OD}$ antimicrobial $) \times 100 / \mathrm{OD}_{\text {bacteria }}$

OD (bacteria): is the $\mathrm{OD}_{600}$ for the positive control, OD (bacteria+ antimicrobial): is the $\mathrm{OD}_{600}$ for the sample treated with phenolic compound and OD (antimicrobial): is the $\mathrm{OD}_{600}$ for the negative control.

\subsection{Determination of minimum lethal concentrations (MLCs) against $S$. Typhimurium:}

The MLCs were assessed in accordance to (CLSI, 2012) where $0.1 \mathrm{ml}$ from each tube that not revealed apparent growth were surface spread onto tryptic soya agar. Plates were incubated for $24 \mathrm{~h}$ at $35^{\circ} \mathrm{C}$. The lowest concentration of tested material showing no growth after incubation was considered as the MLC.

\section{Evaluation of antimicrobial activity of chitosan, chitosan nanoparticles and phenolic-chitosan nanoparticles:}

\subsection{Preparation of nanoparticles (NPs):}

Thymol was the most effective phenolic against $S$. Typhimurium in the present study so, it was chosen for loading on chitosan nanoparticles (CNPs). With slight modification to Medina et al. (2019), thymol loaded chitosan nanoparticles (TLCNPs) were prepared by diluting $1.9 \mathrm{~g}$ of citric acid in a volume of $100 \mathrm{ml}$ of $1 \mathrm{mg} / \mathrm{ml}$ of thymol in water. Then, $300 \mathrm{mg}$ of chitosan (degree of deacetylation within $75-85 \%, \mathrm{Mw}=50,000-$ 190,000 Da, Sigma-Aldrich Co. USA), was added to the mixture and stirred overnight. CNPs were prepared by diluting $300 \mathrm{mg}$ of chitosan in citric acid solution $(1.9 \mathrm{~g} / 100 \mathrm{ml})$. The solutions of chitosan-thymol and chitosan were filtered using a $0.45 \mu \mathrm{m}$ membrane and loaded into two 50-ml syringes mounted on an infusion pump. The rate of solution pumping was $1.8 \mathrm{ml} / \mathrm{min}$ over $50 \mathrm{ml}$ of an aqueous solution of penta sodium tripolyphosphate (TPP, Sigma-Aldrich Co. USA) at $0.1 \%(\mathrm{w} / \mathrm{v})$. The resulted suspension was centrifuged at $24,000 \times \mathrm{g}$ for $30 \mathrm{~min}$. Then the collected supernatant of nanoparticles (NPs) was stored at $4{ }^{\circ} \mathrm{C}$ until use. 


\subsection{Characterization of nanoparticles:}

The procedures recommended by Medina et al. (2019) for characterization was applied using Fourier Transformed Infrared Spectroscopy (FTIR) and zeta potential analysis.

\subsection{Parameters of encapsulation}

Following Medina et al. (2019), a supernatant sample of TLCNPs was dialysed against water for 150 min (using a dialysis tubing cellulose membrane with a molecular weight cut-off of 14,000). The resulted dialysate was then analysed using UV spectrophotometry at $273 \mathrm{~nm}$ following the thymol determination procedures described by Garsuch and Breitkreutz (2010) and Pan et al. (2014); where the dialysate obtained from the CNPs supernatant used as a blank. The lyophilization of dialysated sample was done in a plastic Petri dish with $13.5 \mathrm{~cm}$ diameter, covered with a layer of aluminium foil perforated at $-55{ }^{\circ} \mathrm{C}$ and $6.7 \mathrm{~Pa}$, for a duration of 2 days. Then, the sample was ground with the aid of a porcelain mortar and then stored at $4{ }^{\circ} \mathrm{C}$. The encapsulation parameters were calculated as follows:

Efficiency of encapsulation (EF) $\%=$ Mass of thymol in the supernatant dialysated x100 / Initial thymol mass added

Loading capacity (LC) \% = Mass of thymol in the supernatant dialysated $\mathrm{x} 100$ /Mass of the lyophilized sample.

Yield particles (YP) $\%=$ Mass of the lyophilized sample dialysated x100/ Mass of initial ingredients added

\subsection{Evaluation of thymol release from TLCNPs:}

As recommend by (Raj and Prabha, 2016), a weight of $0.1 \mathrm{mg}$ of TLCNPs was suspended in a volume of $10 \mathrm{ml}$ phosphate buffer saline (PBS) at various $\mathrm{pH}$ at controlled temperature of $37^{\circ} \mathrm{C}$. The obtained suspension was placed in an incubated shaker and continually shacked at rate of $120 \mathrm{rpm}$ for $1 \mathrm{~h}$. Five milliliter aliquots were taken out of the dissolution medium at an intervals of (30 min), replaced by same volume of fresh PBS buffer, for keeping the volume of the release medium constant. The released amount of thymol was observed by UV spectrophotometer at $290 \mathrm{~nm}$.

\subsection{Evaluation of antimicrobial activities of chitosan, CNPs and TLCNPs}

Double fold serial dilutions of the pure materials were carried out using BHIB. The MICs and MLCs against the $S$. Typhimurium were determined by visual and spectrophotometric methods using the same aforementioned techniques.

\section{Antimicrobial activities of thymol and nanoparticles in fish matrix:}

\subsection{Preparation of fish:}

Freshly caught farmed fish named tilapia (Oreochromis niloticus) were descaled, cleaned with tape water, filleted, deboned, portioned into nearly $2.5 \mathrm{~cm} \times 2.5 \mathrm{~cm}$ pieces (10 g each) and used in the experiment.

\subsection{Preparation of antimicrobial solutions:}

The tested materials were prepared at their 1 MIC and 2 MIC using sterile distilled water for making dilutions with DMSO 5\% for thymol and acetic acid $0.25 \%$ for CNPs and TLCNPs as solvents.

\subsection{Inoculation of fish fillet:}

A suitable number of fillets were surface inoculated with calculated inoculum of $10^{5}$ $\mathrm{cfu} / \mathrm{g}$ of $S$. Typhimurium according to (Lang et al., 2004a, b) with slight modification. Inoculated fillets were left for one minute in Biosafety Class II laminar hood to help attachment of inoculum. Then fillets were soaked in antimicrobial solutions for $1 \mathrm{~min}$ and drained for $1 \mathrm{~min}$. A group of inoculated fillets were dipped in sterile distilled water for $1 \mathrm{~min}$ (control). The treated as well as control fillets were sampled for zero time then stored at $4^{\circ} \mathrm{C}$.

\subsection{Microbiological analysis:}

Microbiological analyses were performed for treated and control samples. On a particular sampling time $(0,24,48,72,96 \mathrm{~h})$, fish pieces were transferred individually to stomacher bags and homogenized with Phosphate-buffered saline (PBS; at pH 7.0) to make a 10-fold dilution using stomacher for 2 min. The homogenate was serially diluted with PBS and surface spread in duplicate on 
XLD agar plates for the enumeration of survivors. The seeded plates were incubated at $35^{\circ} \mathrm{C}$ for $24 \mathrm{~h}$ then examined for colonies and counted. Reduction percent in salmonella cells was calculated from the equation

Reduction $\%=($ Count of control - Count of treatment) x 100 / Count of control

\subsection{Effect of thymol and nanoparticles on pH of fish}

On a particular sampling time $(0,24,48,72$,

$96 \mathrm{~h}$ ) a fish fillet were homogenized with 20 $\mathrm{ml}$ distilled water by blendeding for $30 \mathrm{~s}$. The $\mathrm{pH}$ of sample was measured by a digital $\mathrm{pH}$ meter (Gallenhamp No.101284) standardized at $\mathrm{pH} 4$ and 7 as recommended by (Sallam, 2007).

\subsection{Statistical analysis}

The statistical analysis was done using SPSS program for windows (version 12.0.1) according to (SPSS, 2007). The differences between groups were done by using of a Student "t"-test. Significance level was considered at $\mathrm{P}<0.05$.

\section{RESULTS}

Table 1: Minimum inhibitory concentrations (MICs) and minimum lethal concentrations (MLCs) of phenolics (mg/ml) against $S$. Typhimurium.

\begin{tabular}{lccc}
\hline \multirow{2}{*}{ Phenolic compounds } & \multicolumn{2}{c}{ MICs } & \multirow{2}{*}{ MLCs } \\
\cline { 2 - 3 } & Visual method & Spectrophotometric method & \\
\hline Thymol (Th) & $0.08 \pm 0.01^{\mathrm{a}}$ & $0.16 \pm 0.02^{\mathrm{b}}$ & 0.08 \\
\hline Gallic acid (GA) & $10.00 \pm 1.49$ & $10.00 \pm 1.55$ & 10.00 \\
\hline Cinnamic acid (CA) & $5.00 \pm 0.79$ & $5.00 \pm 0.79$ & 5.00 \\
\hline Benzoic acid (BA) & $1.25 \pm 0.14^{\mathrm{a}}$ & $2.50 \pm 0.44^{\mathrm{b}}$ & 2.50 \\
\hline Coumarin & $2.50 \pm 0.37$ & $2.50 \pm 0.32$ & $\uparrow 10.00$ \\
\hline \multirow{2}{*}{ Curcumine } & $10.00 \pm 1.57^{\mathrm{a}}$ & $5.00 \pm 0.79^{\mathrm{b}}$ & 10.00 \\
\hline
\end{tabular}

*In the same raw means with different superscript letters are significantly different $(p<0.05)$

Table 2: Growth inhibition percentages (GI \%) produced by phenolics against $S$. Typhimurium.

\begin{tabular}{cc}
\hline Phenolics $(\mathbf{m g} / \mathbf{m l})$ & GI \% \\
\hline Thymol $(0.16)$ & 100.00 \\
\hline Thymol $(0.08)$ & 55.30 \\
\hline Gallic acid (10.00) & 100.00 \\
\hline Gallic acid (5.00) & 94.10 \\
\hline Cinnamic acid (5.00) & 100.00 \\
\hline Cinnamic acid (2.50) & 90.40 \\
\hline Cinnamic acid (1.25) & 61.77 \\
\hline Benzoic acid (2.50) & 100.00 \\
\hline Benzoic acid (1.25) & 98.20 \\
\hline Benzoic acid (0.63) & 85.90 \\
\hline Curcumine (5.00) & 100.00 \\
\hline Coumarin $(2.50)$ & 100.00 \\
\hline Coumarin $(1.25)$ & 74.50 \\
\hline
\end{tabular}


Table 3: Encapsulation parameters of nanoparticles.

\begin{tabular}{cc}
\hline Parameter & Percent \\
\hline Encapsulation efficiency of TLCNPs & 99.54 \\
\hline Loading capacity of TLCNPs & 64.17 \\
\hline Yield particles of TLCNPs & 96.30 \\
\hline Yield particles of CNPs (control) & 99.45 \\
\hline
\end{tabular}

Table 4: Minimum inhibitory concentrations (MICs) and minimum lethal concentrations (MLCs) of chitosan, CNPs and CLCNPs against $S$. Typhimurium.

\begin{tabular}{cccc}
\hline \multirow{2}{*}{ Treatments } & \multicolumn{2}{c}{ MICs (mg/ml) mean values } & MLCs \\
\cline { 2 - 3 } & Visual method & $\begin{array}{c}\text { Spectrophotometric } \\
\text { method }\end{array}$ & $(\mathbf{m g} / \mathbf{m l})$ \\
\hline Chitosan & $0.63 \pm 0.07$ & $0.63 \pm 0.09$ & 0.63 \\
\hline CNPs & $0.80 \pm 0.13$ & $0.80 \pm 0.13$ & 1.60 \\
\hline TLCNPs & $0.80 \pm 0.16$ & $0.80 \pm 0.19$ & 1.60 \\
\hline
\end{tabular}

Table 5: Growth inhibition percentages (GI\%) produced by chitosan, CNPs and TLCNPs against $S$. Typhimurium

\begin{tabular}{cc}
\hline Treatments $(\mathbf{m g} / \mathbf{m l})$ & GI \% \\
\hline Chitosan $(0.625)$ & 100 \\
\hline CNPs $(0.8)$ & 100 \\
\hline TLCNPs $(0.8)$ & 100 \\
\hline
\end{tabular}

Table 6: Effect of thymol minimum inhibitory concentration (MIC) and (2 MIC) on quality of fish inoculated with $S$. Typhimurium and stored at $4^{\circ} \mathrm{C}$.

\begin{tabular}{|c|c|c|c|c|c|}
\hline \multirow{3}{*}{ Sampling time } & \multirow{3}{*}{$\begin{array}{c}\text { Conc. } \\
(\mathrm{mg} / \mathrm{ml})\end{array}$} & \multicolumn{4}{|c|}{ Quality parameters } \\
\hline & & \multicolumn{2}{|c|}{ S. Typhimurium (cfu/g) } & \multicolumn{2}{|c|}{ pH value } \\
\hline & & Control & Treatment & Control & Treatment \\
\hline \multirow{2}{*}{ Zero h } & 0.08 & \multirow{2}{*}{$6 \times 10^{4} \pm 15811$} & $1 \times 10^{4 *} \pm 2236$ & \multirow{2}{*}{$5.2 \pm 0.71$} & $5.8 \pm 0.99$ \\
\hline & 0.16 & & $1 \times 10^{3 *} \pm 353$ & & $6.0 \pm 0.46$ \\
\hline \multirow{2}{*}{$24 \mathrm{~h}$} & 0.08 & \multirow{2}{*}{$6 \times 10^{4} \pm 22360$} & $3 \times 10^{4 *} \pm 2121$ & \multirow{2}{*}{$5.5 \pm 0.91$} & $5.5 \pm 0.94$ \\
\hline & 0.16 & & $1 \times 10^{4 *} \pm 1414$ & & $5.6 \pm 0.96$ \\
\hline \multirow{2}{*}{$48 \mathrm{~h}$} & 0.08 & \multirow{2}{*}{$6.2 \times 10^{4} \pm 707$} & $5 \times 10^{4 * \pm 1581}$ & \multirow{2}{*}{$5.5 \pm 0.75$} & $6.1 \pm 0.53$ \\
\hline & 0.16 & & $8 \times 10^{3 *} \pm 2319$ & & $6.2 \pm 1.06$ \\
\hline \multirow{2}{*}{$72 \mathrm{~h}$} & 0.08 & \multirow{2}{*}{$6.7 \times 10^{4} \pm 108$} & $5 \times 10^{4 *} \pm 353$ & \multirow{2}{*}{$5.6 \pm 0.76$} & $5.4 \pm 1.45$ \\
\hline & 0.16 & & $1 \times 10^{4 * \pm 707}$ & & $5.7 \pm 0.97$ \\
\hline \multirow{2}{*}{$96 \mathrm{~h}$} & 0.08 & \multirow{2}{*}{$7 \times 10^{5} \pm 70710$} & $1 \times 10^{5 * \pm 1523}$ & \multirow{2}{*}{$6.0 \pm 1.14$} & $5.0 \pm 0.46$ \\
\hline & 0.16 & & $8 \times 10^{4 *} \pm 1423$ & & $4.8 \pm 0.44$ \\
\hline
\end{tabular}

$*=$ Difference between treatment and control is significant $(\mathrm{p}<0.05)$ 
Table 7: Effect of CNPs minimum inhibitory concentration (MIC) and 2 MIC) on quality of fish inoculated with $S$. Typhimurium and stored at $4^{\circ} \mathrm{C}$.

\begin{tabular}{|c|c|c|c|c|c|}
\hline \multirow{3}{*}{$\begin{array}{c}\text { Sampling } \\
\text { time }\end{array}$} & \multirow{3}{*}{$\begin{array}{l}\text { Conc. } \\
\text { (mg/ml) }\end{array}$} & \multicolumn{4}{|c|}{ Quality parameters } \\
\hline & & \multicolumn{2}{|c|}{ S. Typhimurium (cfu/g) } & \multicolumn{2}{|c|}{ pH value } \\
\hline & & Control & Treatment & Control & Treatment \\
\hline \multirow{2}{*}{ Zero h } & 0.8 & \multirow{2}{*}{$6 \times 10^{4} \pm 15811$} & $5 \times 10^{4} \pm 5533$ & \multirow{2}{*}{$5.2 \pm 0.71$} & $5.5 \pm 0.61$ \\
\hline & 1.6 & & $3 \times 10^{4} \pm 3313$ & & $5.3 \pm 0.92$ \\
\hline \multirow{2}{*}{$24 \mathrm{~h}$} & 0.8 & \multirow{2}{*}{$6 \times 10^{4} \pm 22360$} & $1 \times 10^{4} \pm 110$ & \multirow{2}{*}{$5.5 \pm 0.91$} & $5.1 \pm 0.56$ \\
\hline & 1.6 & & $<100 *$ & & $5.2 \pm 0.90$ \\
\hline \multirow{2}{*}{$48 \mathrm{~h}$} & 0.8 & \multirow{2}{*}{$6.2 \times 10^{4} \pm 707$} & $<100 *$ & \multirow{2}{*}{$5.5 \pm 0.75$} & $6.1 \pm 0.67$ \\
\hline & 1.6 & & $<100 *$ & & $6.1 \pm 1.06$ \\
\hline \multirow{2}{*}{$72 \mathrm{~h}$} & 0.8 & \multirow{2}{*}{$6.7 \times 10^{4} \pm 1081$} & $2 \times 10^{3} \pm 221$ & \multirow{2}{*}{$5.6 \pm 0.76$} & $6.0 \pm 0.66$ \\
\hline & 1.6 & & $2 \times 10^{3} \pm 220$ & & $6.1 \pm 1.06$ \\
\hline \multirow{2}{*}{$96 \mathrm{~h}$} & 0.8 & \multirow{2}{*}{$7 \times 10^{5} \pm 7071$} & $2 \times 10^{4} \pm 3478$ & \multirow{2}{*}{$6.0 \pm 1.14$} & $6.0 \pm 0.66$ \\
\hline & 1.6 & & $1 \times 10^{4} \pm 1106$ & & $6.1 \pm 0.67$ \\
\hline
\end{tabular}

$*=$ Difference between treatment and control is significant $(\mathrm{p}<0.05)$

Table 8: Effect of TLCNPs minimum inhibitory concentration (MIC) and (2 MIC) on quality of fish inoculated with $S$. Typhimurium and stored at $4^{\circ} \mathrm{C}$.

\begin{tabular}{|c|c|c|c|c|c|}
\hline \multirow{3}{*}{ Sampling time } & \multirow{3}{*}{$\begin{array}{c}\text { Conc. } \\
\text { (mg/ml) }\end{array}$} & \multicolumn{4}{|c|}{ Quality parameters } \\
\hline & & \multicolumn{2}{|c|}{ S. Typhimurium (cfu/g) } & \multicolumn{2}{|c|}{ pH value } \\
\hline & & Control & Treatment & Control & Treatment \\
\hline \multirow{2}{*}{ Zero h } & 0.8 & \multirow{2}{*}{$6 \times 10^{4} \pm 15811$} & $2 \times 10^{4 *} \pm 2209$ & \multirow{2}{*}{$5.2 \pm 0.71$} & $4.9 \pm 0.54$ \\
\hline & 1.6 & & $1 \times 10^{4 * \pm 1104}$ & & $4.4 \pm 0.49$ \\
\hline \multirow{2}{*}{$24 \mathrm{~h}$} & 0.8 & \multirow{2}{*}{$6 \times 10^{4} \pm 22360$} & $1 \times 10^{2 * \pm 0}$ & \multirow{2}{*}{$5.5 \pm 0.91$} & $4.6 \pm 0.51$ \\
\hline & 1.6 & & $<100 *$ & & $4.6 \pm 0.54$ \\
\hline \multirow{2}{*}{$48 \mathrm{~h}$} & 0.8 & \multirow{2}{*}{$6.2 \times 10^{4} \pm 707$} & $<100 *$ & \multirow{2}{*}{$5.5 \pm 0.75$} & $5.4 \pm 0.63$ \\
\hline & 1.6 & & $<100 *$ & & $5.4 \pm 0.72$ \\
\hline \multirow{2}{*}{$72 \mathrm{~h}$} & 0.8 & \multirow{2}{*}{$6.7 \times 10^{4} \pm 1081$} & $1 \times 10^{4 * \pm 919}$ & \multirow{2}{*}{$5.6 \pm 0.76$} & $5.4 \pm 0.63$ \\
\hline & 1.6 & & $1 \times 10^{3 *} \pm 135$ & & $5.3 \pm 0.62$ \\
\hline \multirow{2}{*}{$96 \mathrm{~h}$} & 0.8 & \multirow{2}{*}{$7 \times 10^{5} \pm 70710$} & $1 \times 10^{4 * \pm 1142}$ & \multirow{2}{*}{$6.0 \pm 1.14$} & $5.8 \pm 0.68$ \\
\hline & 1.6 & & $1 \times 10^{3 *} \pm 110$ & & $5.7 \pm 0.67$ \\
\hline
\end{tabular}

\footnotetext{
$*=$ Difference between treatment and control is significant $(\mathrm{p}<0.05)$
}

Table 9: Reduction percentages produced by antimicrobials minimum inhibitory concentration (MIC) and (2MIC) in fish inoculated with $S$. Typhimurium and stored at $4^{\circ} \mathrm{C}$

\begin{tabular}{|c|c|c|c|c|c|c|}
\hline \multirow{2}{*}{ Sampling times } & \multicolumn{2}{|c|}{ Thymol } & \multicolumn{2}{|c|}{ CNPs } & \multicolumn{2}{|c|}{ TLCNPs } \\
\hline & $\begin{array}{c}0.08 \\
(\mathrm{mg} / \mathrm{ml})\end{array}$ & $\begin{array}{c}0.16 \\
(\mathrm{mg} / \mathrm{ml})\end{array}$ & $\begin{array}{c}0.8 \\
(\mathrm{mg} / \mathrm{ml})\end{array}$ & $\begin{array}{c}1.6 \\
(\mathrm{mg} / \mathrm{ml})\end{array}$ & $\begin{array}{c}0.8 \\
(\mathrm{mg} / \mathrm{ml})\end{array}$ & $\begin{array}{c}1.6 \\
(\mathrm{mg} / \mathrm{ml})\end{array}$ \\
\hline $0 \mathrm{~h}$ & 83 & 98 & 17 & 50 & 67 & 83 \\
\hline $24 \mathrm{~h}$ & 50 & 83 & 83 & 100 & 100 & 100 \\
\hline $48 \mathrm{~h}$ & 19 & 87 & 100 & 100 & 100 & 100 \\
\hline $72 \mathrm{~h}$ & 25 & 85 & 97 & 97 & 85 & 99 \\
\hline $96 \mathrm{~h}$ & 86 & 89 & 97 & 99 & 99 & 100 \\
\hline
\end{tabular}




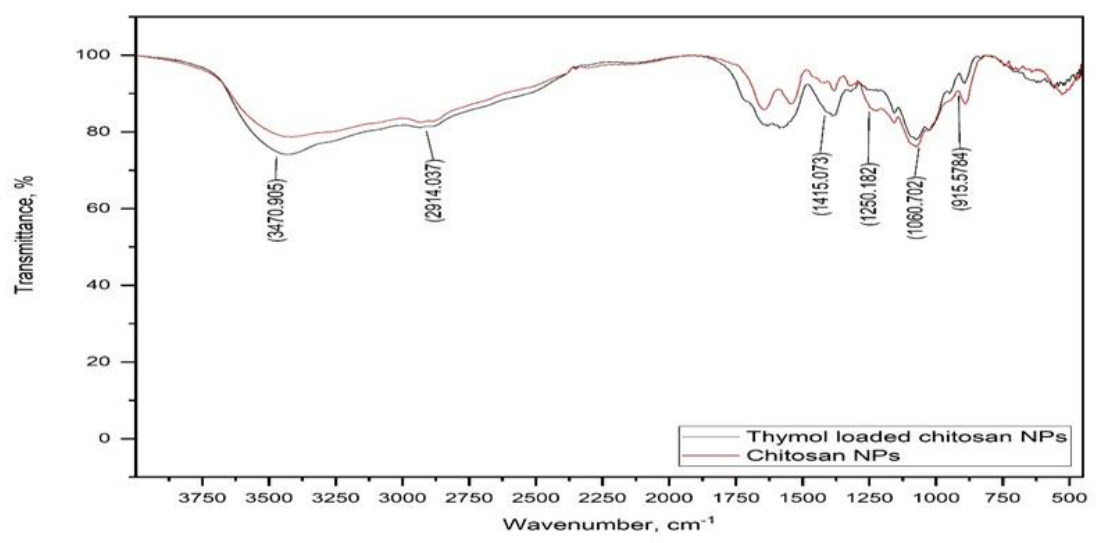

Figure 1. FTIR spectra of TLCNPs and CNPs

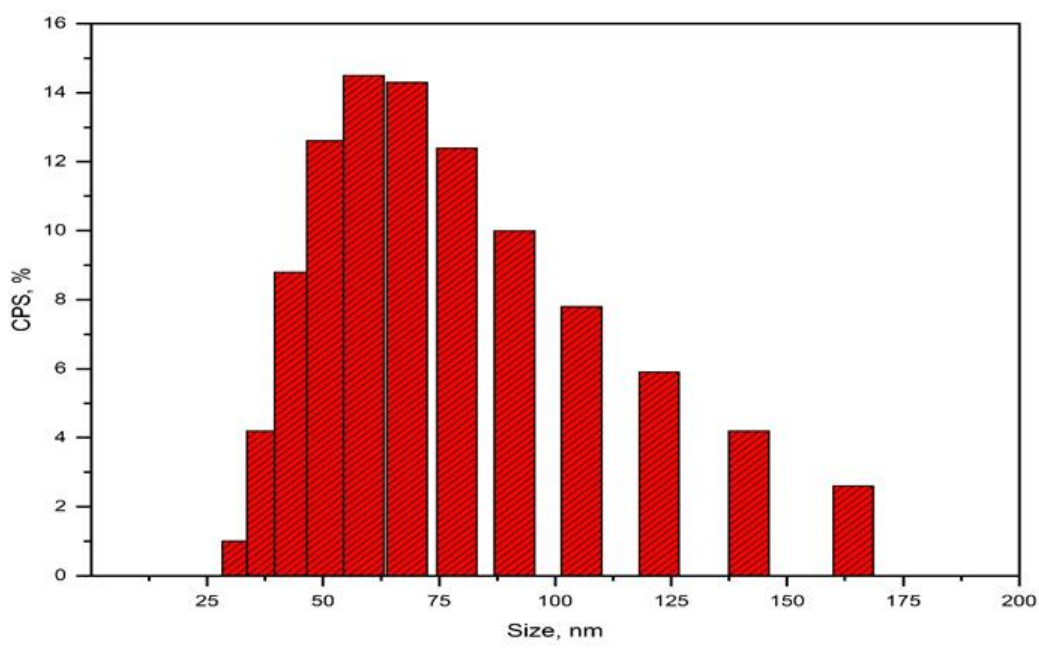

Figure 2. Particle size distribution of TLCNPs

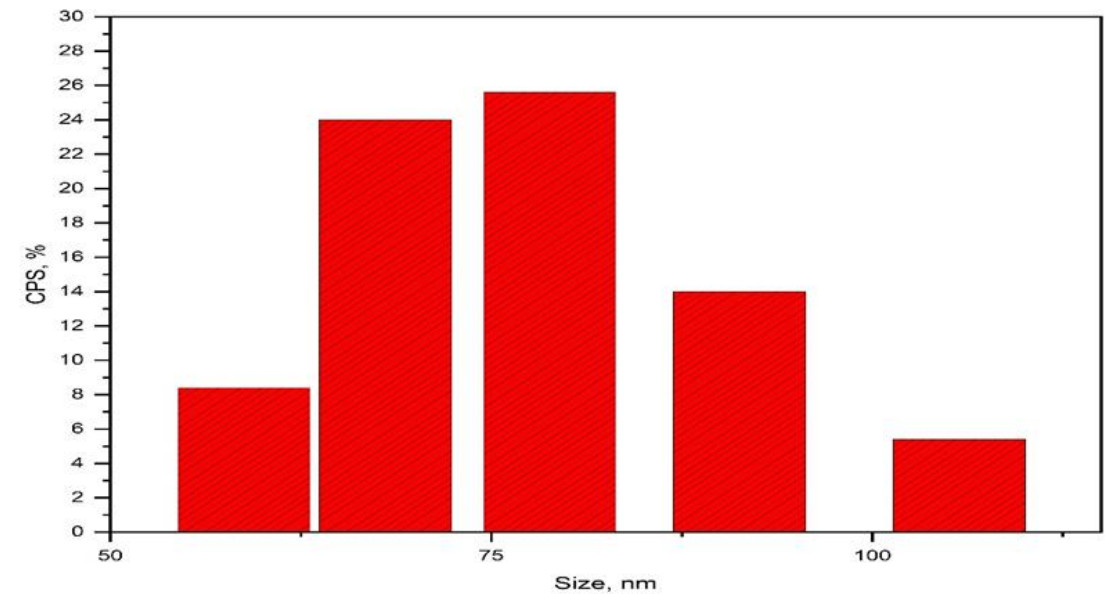

Figure 3. Particle size distribution of CNPs 


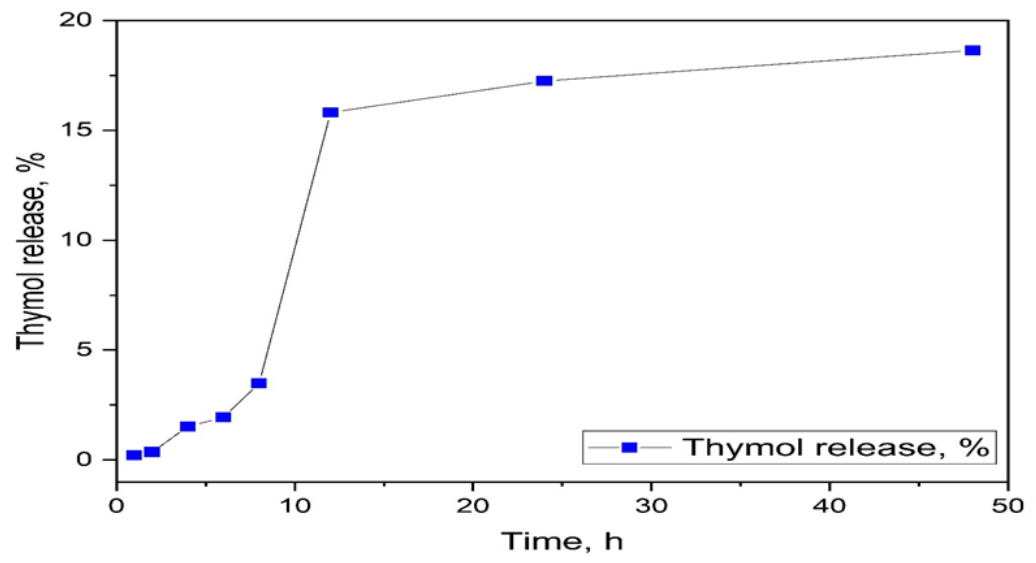

Figure 4. Thymol release profile from TLCNPs

\section{DISCUSSION}

\section{Effect of phenolics against $S$. Typhimurium}

Food safety is an important global concern for consumers and traders. Thus control measures are essentials to avoid the spreading of pathogens along the food chain. Phenolics such as curcumine and phenolic acids are common in the Egyptian folk medicine and traditional food additives. Phenolics mainly attack the microorganisms through enzyme inhibition by the effect of oxidized compounds, through reaction with sulfhydryl groups or through more non-specific interactions with proteins resulting in their inactivation and loss of function (Akhtar et al., 2015).

The data in (Table 1) summarizes the activity of phenolics against $S$. Typhimurium. By visual assay, the MICs varied from 0.08 to $10.00 \mathrm{mg} / \mathrm{ml}$ while the corresponding values for spectrophotometric method were 0.16 to $10.00 \mathrm{mg} / \mathrm{ml}$. The most powerful effect was obtained by thymol. It could inhibit and kill Salmonella at concentration of $0.08 \mathrm{mg} / \mathrm{ml}$. Thymol was reported to have antiseptic action and is included in the American Food and Drug Administration (FDA) as an antibacterial and antifungal agent (Meeran et al., 2017). Besides it is classified by the FDA as generally recognized as safe (GRAS), (Llana-Ruiz-Cabello et al., 2015).

Thymol was reported to disintegrate the outer membrane of Gram negative bacteria (Engels et al., 2009). Also, Chauhan and Kang (2014) recorded that thymol kills Salmonella by the same action and reported MIC value of $750 \mathrm{mg} / \mathrm{ml}$. The activity of thymol against $S$. Typhimurium was also explored by studies of Silva-Angulo et al. (2015) and Gómez-García et al. (2019).

Organic acids have a vital role in food preservation. They function to maintain the microbiological quality of meat and meat products (Sánchez-Ortega et al., 2014) and commonly incorporated into edible coating (Cagri et al., 2003). The antimicrobial activity of phenolic acids is related to their chemical structure, especially the number and position of substitution in the benzene ring, and the length of saturated chain (Cueva et al., 2010). Also increasing length of the alkyl chain increases the activity (Merkl et al., 2010).

Gallic acid is a phenolic with many industrial applications, such as antioxidant in food and antimicrobial agent in the drug industry (Mota et al., 2010). In the current study gallic acid was inhibitor to $S$. Typhimurium with MIC of $10.00 \mathrm{mg} / \mathrm{ml}$ for both visual and spectrophotometric 
methods, (Table 1). The same concentration also appeared lethal effect. The calculated inhibition \% corresponding to the MIC concentration $(10.00 \mathrm{mg} / \mathrm{ml})$ was $100 \%$ while lower concentration $(5.00 \mathrm{mg} / \mathrm{ml})$ produced only growth inhibition of $94.1 \%$, (Table 2). Gallic acid fights bacteria through affecting the integrity of the cytoplasmic membrane which leads to loss of ingredients and inhibiting activity of respiratoin (Fitzgerald et al., 2004).

In a related study, treatment with gallic acid resulted reduction of $1.5 \mathrm{log} \mathrm{cfu} / \mathrm{ml}$ of $S$. Typhimurium and L. monocytogenes (Ravichandran et al., 2011). Meanwhile, the activity of gallic acid was found to be lowered by two- to tenfold compared to other hydroxybenzoic acids (SánchezMaldonado et al., 2011). Furthermore, Gullon et al. (2016) related the activity of pomegranate juice against $S$. Typhimurium to its richness in gallic acid.

Cinnamic acid was considered by FDA as safe food additive for flavor enhancement. In the common flavor usage, it does not exceed $31 \mathrm{mg} / 1$ (Committee, F. W. E., 2001). In the present study, cinnamic acid showed a powerful inhibitory effect against $S$. Typhimurium. Its MICs were $5.00 \mathrm{mg} / \mathrm{ml}$ by visual and spectrophotometric methods where the inhibition was proportional to concentration (Table 1 and 2). Also it was cidal to salmonella cells at $5.00 \mathrm{mg} / \mathrm{ml}$. A related study by Olasupo et al. (2003) recorded that cinnamic acid at $1 \mathrm{~g} / \mathrm{L}$ had antimicrobial properties against Salmonella.

Benzoic acid is relatively nontoxic (CIREPBN, 2001) and was not recorded to accumulate in the body. Following ingestion, it is rapidly absorbed from the gastrointestinal tract and metabolized to nhippuric acid in the liver (HSDB, 1997). The ideal levels of application of benzoic acid as a preservative in food ranged $0.05-$ $0.1 \%$ (GSFA, 2007). In the present study, benzoic acid exhibited a marked antibacterial activity against $S$.
Typhimurium where its MICs were 1.25 $\mathrm{mg} / \mathrm{ml}$ by visual method and $2.50 \mathrm{mg} / \mathrm{ml}$ by spectrophotometric method. The MLC to salmonella cells was $2.50 \mathrm{mg} / \mathrm{ml}$ (Tables 1). By comparison, Ravichandran et al. (2011) reported that the MIC of benzoic acid against $S$. Typhimurium and $L$. monocytogenes was $5,000 \mu \mathrm{g} / \mathrm{ml}$ for each. Moreover, Alves et al. (2013) recorded that 2, 4-Dihydroxybenzoic acid appeared a broad spectrum antibacterial activity.

The antibacterial activity of benzoic acid has been attributed to its ability to act on cell wall, penetrate and inhbit enzymatic functions (Luck and Jager, 1997).The pKa and the lipophilicity are the main solubility determinants of phenolic acids in bacterial membranes (Campos et al., 2009). Their lipophilicity are influenced by $\mathrm{pH}$ which governs the charge of the carboxyl group and also by substitutions of hydroxyl and methoxy groups on the ring (SánchezMaldonado et al., 2011). Thus both hydroxybenzoic acids and hydroxycinnamic acids are considered weak organic acids but differ in the properties of lipophilicity and activities.

Curcumine is nontoxic, bioactive agent of turmeric that has been utilized in traditional medicine (Jahromi et al., 2014). In current study, curcumine demonstrated both inhibitory and lethal effects when tested against $S$. Typhimurium. By visual method, its MIC was $10.00 \mathrm{mg} / \mathrm{ml}$ while by spectrophotometric method was $5.00 \mathrm{mg} / \mathrm{ml}$ (Table 1) with a growth inhibition varying with the concentration (Table 2). In a related study, Singh et al. (2010) declared that curcumine is a potent molecule in the treatment of bacterial infections. Also Rai et al. (2008) and Bhawana et al. (2011) suggested that curcumine is considered as an important antibacterial.

Coumarins were recorded to have speciesdependent metabolism. In human bodies, coumarin derivatives were reported to excreted in urine without adverse health 
effects (Venugopala et al., 2013). The findings of the present study showed that at a concentration of $2.50 \mathrm{mg} / \mathrm{ml}$ as a MIC, coumarin inhibited the growth of $S$. Typhimurium by $100 \%$ while the MLC was $10.00 \mathrm{mg} / \mathrm{ml}$ (Tables 1, 2). In this respect, Lou et al. (2012) recorded MIC of $80 \mu \mathrm{g} / \mathrm{ml}$ of p-coumaric acid against $E$. coli and $S$. Typhimurium. Their study explained that, like other phenols, that compound changes the permeability of the cell membrane and can bind DNA and impair cell function. In a related research work, 2, 4-dihydroxybenzoic, p-coumaric acids and cinnamic acid derivatives were the compounds that showed powerful broad spectrum of antimicrobial activity (Alves et al., 2013).

The present study shared Alves et al. (2013) explanation that the observed difference in MICs with other studies may be related to the use of strains with different susceptibility profiles. Moreover, different studies dealt with different methodologies of antibacterial activity assessment, and organisms revealed variation in the sensitivity to phenolics (SánchezMaldonado et al., 2011). Also, comparing the effect of natural antimicrobials, is often difficult, due to the use of different approaches endpoints determination (Balouiri et al., 2016).

Broth dilution is approved by CLSI for testing aerobic growing bacteria (CLSI, 2012). Broth micro and macro-dilution are considered the most basic anti- microbial activity testing methods. Compared to micro-dilution method, the main disadvantages of the macro-dilution method are manual undertaking, and the comparatively large amount of antimicrobial solutions and space required (Jorgensen and Ferraro, 2009). So, reproducibility and little volume of reagents (CLSI, 2012) besides, ease determination of MIC endpoint by viewing devices (readers) are major advantages of the micro-dilution method. These advantages made EUCAST
(2003) recommended spectrophotometric method in reading MIC endpoint as modifications to CLSI guide lines (Arikan, 2007).

The results in (Tables 1 and 4) revealed that MIC values by spectrophotometric method were significantly different compared to visual method in some antimicrobial assays and nearly agreed in most others. In this respect, Devienne and Raddi (2002) compared spectrophotometric to visual method in reading MIC for natural antimicrobials and recorded $100 \%$ correlation of the methods. That was true also for Lindqvist (2006) who recorded that determination of MIC by measuring turbidity matched with count method. While Nguyen and Yu (1999) concluded that visual reading is not as accurate as spectrophotometric for MIC end points.

\section{Effect of chitosan against $S$. Typhimurium}

Chitosan is a high molecular weight cationic polysaccharide, resulted from the deacetylation of chitin (De Reuck et al., 2009). Due to its biocompatibility and biodegradability, chitosan attracted attention as a natural additive to food. When chitosan comes in contact with susceptible microorganism, and as a positively charged polymer interact with bacterial membrane possessing a negative charge. As a result, low-molecular weight materials, nucleic acids, and proteins, are leached out (Alishahi and Aïder, 2012).

Chitosan was used in the present study as nano deliver to thymol. Its activity against $S$. Typhimurium was investigated in the preliminary work. Chitosan was inhibitor to $S$. Typhimurium at $0.63 \mathrm{mg} / \mathrm{ml}$ by visual and spectrophotometric methods (Table 4) with growth inhibition $100 \%$ (Table 5). Also the MLC was $0.63 \mathrm{mg} / \mathrm{ml}$. In comparison, Menconi et al. (2014) mentioned that chitosan at a concentration of $0.2 \%$ significantly declined the count of recovered $S$. Typhimurium compared with 
control. Also Kong et al. (2010) recorded that both chitosan and its derivatives are more potent antibacterial agents when tested against Gram negative bacteria. Meanwhile, Fernandez-Sainz et al. (2010) summarized the factors influence the effectiveness of chitosan as: the physicochemical properties (molecular weight, degree of acetylation), $\mathrm{pH}$ of the solution and the tested microorganism. These factors also may explain difference of results for different studies.

\section{Formation of polyphenolic nanocapsules}

Many of the phenolic compounds have the properties of poor water solubility, low stability and the little bioavailability (Gupta et al., 2016). Nanoencapsulation can aid to overcome such problems (Conte et al., 2016). That type of technology was tried in the present study with thymol as it appeared the highest antibacterial activity against $S$. Typhimurium. It was chosen for encapsulation to study its efficiency under controlled release. The polymeric encapsulating agent used in this study was chitosan.

\subsection{Encapsulation efficiency percentage (EE \%)}

The amount of bioactive compounds could be entrapped within the nanoparticles is a marker of encapsulation efficiency (Vashisth et al., 2015). It is advantageous for the encapsulation efficiency to be as near to 100 $\%$ as possible. Where high encapsulation efficiency leads to better targeted delivery. The summarized data in Table 3 cleared that $99.54 \%$ of the total thymol was encapsulated with loading capacity of 64.17 $\%$. The yield particles of TLCNPs was 96.3 $\%$, while yield particles of CNPs (control) was $99.45 \%$.

\subsection{Fourier Transmission Infrared spectroscopy (FTIR)}

The results of FTIR study (Figure 1) showed for TLCNPs at 3470, 2914, 1415, 1250, 1060, and $915,816 \mathrm{~cm}^{-1}$ represent the hydrogen-bonded $\mathrm{O}-\mathrm{H}$ stretch band, $\mathrm{CH}$ stretching vibration corresponding to aldehyde compound, $\mathrm{NH} 3, \mathrm{OH}$ group in $\mathrm{CH} 3$ back bone, carbon ring in cyclic compound and $\mathrm{OH}$ group in phenol rvealing the presence and formation of hydrogen bonds with aliphatic compounds, primary amines and primary alcohols. The intense broad band peak at $3430 \mathrm{~cm}^{-1}$ was characterized for the hydroxyl functional group in alcohol and phenol compounds.

\subsection{Zeta Sizer analysis}

The zeta potential of the TLCNPs and CNPs were found to be $54.80 \mathrm{mV}$, and $34.50 \mathrm{mV}$, respectively. The particle size distribution of the TLCNPs and CNPs were shown in (Figures 2, 3) respectively.

\section{4. Thymol release}

Figure 4 shows the release profile of thymol from CNPs at $\mathrm{pH}$ 7.4. It was found that a slight release of thymol until $8 \mathrm{~h}$ to be 3.50 $\%$. Then, a slight increase in the release was shown being $15.81 \%$ after $12 \mathrm{~h}$. In addition, the release was achieved $18.64 \%$ from $12 \mathrm{~h}$ to $48 \mathrm{~h}$ which indicating the stability of thymol in CNPs.

\section{Effect of CNPs and TLCNPs against $S$. Typhimurium}

Besides serving as a carrier for controlling release of the active compound, binding the core with phenolic compounds also allows for the protection from adverse effects of light, heat, and oxygen (Soto-Chilaca et al., 2016). In present study, the MIC of CNPs against $S$. Typhimurium was $0.8 \mathrm{mg} / \mathrm{ml}$ by visual and spectrophotometric methods with growth inhibition $100 \%$ while the MLC was $1.6 \mathrm{mg} / \mathrm{ml}$ (Tables 4, 5). In a related study using representative strains of Gram negative and Gram positive bacteria, CNPs showed antibacterial effect in concentrations not less than $0.3 \%$ (Ghaderi-Ghahfarokhi et al., 2017). Also it is recorded that CNPs were more efficient than chitosan solution at enhancing drug activity (Ma et al., 2005). By the regard, the larger surface area of nanoparticles resulted better distribution and 
potency of packaged phenolic molecules (Redhead et al., 2001). Also Abdou et al. (2012) recorded that chitosan nanoparticles had higher antimicrobial effect than chitosan.

TLCNPs exhibited nearly the same effect of chitosan CNPs activity against $S$. Typhimurium where its MIC was $0.8 \mathrm{mg} / \mathrm{ml}$ by visual and spectrophotometric methods with growth inhibition $100 \%$ while MLC was $1.6 \mathrm{mg} / \mathrm{ml}$ (Tables 4, 5). Loading phenolics on nano-deliver function in protection and control of release. In this respect, Lapidot et al. (2002) reported that due to interaction of phenolics with medium components their potency lost with time. Meanwhile, Ravichandran et al. (2011) recorded that by packaging in nanoparticles, phenolics could be protected from the components of media and thus retaining their potency. Also the chitosan shells could protect the enclosed bioactive compounds from natural degradation such as hydrolysis (Kim et al., 2008).

Chitosan- phytochemical conjugates (CPCCs) were found to increase the osmotic pressure, induce disruption and shrinkage of the bacterial membrane and reduce its permeability to intracellular components (Eom et al., 2015). Another explanation was mentioned by Kong et al. (2010) where CPCCs form a barrier on the bacterial surface and prevent passing of nutrients.

\section{Effect of thymol and nanoparticles on survival of $S$. Typhimurium and $\mathrm{pH}$ of treated fish fillets}

Edible coatings are food grade suspensions which upon drying cover the food surface with clear thin layer (Sánchez-Ortega et al., 2014). These coatings can act as carriers of substances to inhibit pathogenic microorganisms. That type of processing was tried in present study using thymol solution. Thymol is a natural phenolic compound present in the essential oil fraction of Thymus plants (Juven et al.,
1994). It is permitted by USFDA (2014) as additive to food for human consumption.

The data summarized in (Table 6 and 9) revealed that just after dipping in coating solution containing the MIC of thymol ( 0.08 $\mathrm{mg} / \mathrm{ml}$ ), the count of $S$. Typhimurium survivors in fish fillets was significantly $(\mathrm{p}<0.05)$ reduced $(83 \%$ reduction) compared to control. By application of 2MIC, the reduction increased to $98 \%$. During refrigerator storage and by MIC, the effect of thymol showed fluctuation in activity where after $24 \mathrm{~h}$ the reduction declined to $50 \%$. The declined reduction continued during the two successive days to reach $25 \%$ by end of $72 \mathrm{~h}$ but still significant. Then reduction increased again to reach $86 \%$ by end of $96 \mathrm{~h}$. Using $2 \mathrm{MIC}$ and during refrigerated storage the effect was significant with slight fluctuation where reduction was within the range of 83$89 \%$, (Table9).

Thymol has been shown to exhibit antibacterial activity including food pathogens (Delgado et al., 2004). That effect was attributed to impairing the cytoplasmic membrane through the destruction of the lipid bilayer in (Lambert et al., 2001) which results an efflux of ions and ATP with proton motive force dissipation and eventually cell death (Guevara et al., 2015).

For flesh foods, $\mathrm{pH}$ is an important quality index. It is one of the most important factors in affecting microbial growth and deterioration of foods (Anvari et al., 2012). Meanwhile, ES 3494/ (2005) recommended a value of 6.5 as a maximum level of $\mathrm{pH}$ for cold stored fish. By the two applied concentrations, thymol coating resulted slightly alkalizing effect to fish fillets compared to control. That effect was not significant and the $\mathrm{pH}$ value still within recommended values, (Table 9).

Chitosan is representing one of biopolymers that are safe for human consumption .Besides it has several effective delivery methods (Hintz et al., 2015). Its films are 
advantageous as they are semipermeable, durable, long-lasting and inexpensive. In the current study, coating of fillets with solution containing particles within nanoscale was tried with chitosan. CNPs showed potential reduction against $S$. Typhimurium. Application of MIC $(0.8 \mathrm{mg} / \mathrm{ml})$ produced potential delayed effect while the $2 \mathrm{MIC}$ showed potential on both immediate and delayed effect. Salmonella cells were reduced by $17 \%$ after immediate coating with MIC of CNPs compared to a significant reduction $(50 \%)$ by $2 \mathrm{MIC}$ trial (Table 7,9$)$. The CNPs activity continued increasing and the effect was maximized (100\% reduction) at $48 \mathrm{~h}$ storage for MIC application and during 24-48h for 2MIC trial. Then effect for both trials still nearly constant and significant till the end of storage time (96h). The degree of activity of nano-antimicrobials was found to depend on outer structural arrangement of the bacterial wall where the amount of time needed for nanoparticles penetration varied accordingly (Mazumder $e t$ al., 2013).

By application of CNPs coating, treated fillets appeared slight alkalinity at some sampling periods but not significantly affected, (Tables 7). The same observation was reported by Mohan et al. (2012) by application of 1 and $2 \%$ chitosan coatings to frozen-stored sardines.

By Nanoencapsulation of phenolics unpleasant taste and aroma can be masked, release can be controlled and solubility of lipophilic compounds can be improved (Pisoschi et al., 2017). In current study, application of TLCNPs increased the safety of fish fillets in concern with salmonella. From (Tables 8, 9), the effect of coating of fillets with TLCNPs produced immediate reduction in salmonella cells by 67 and $83 \%$ for MIC $(0.8 \mathrm{mg} / \mathrm{ml})$ and 2MIC trials, respectively. By proceeding of time at refrigerator storage, the activity of TLCNPs against salmonella was maximized by end of $24 \mathrm{~h}$ and still potential within the three successive days. These findings agreed with those of Ravichandran et al. (2011) who reported that nanoparticles can act as a successful delivery system for phenolic compounds and enhancing their antimicrobial efficacy. In related studies, loading phenolic compounds to polymeric nanoparticles resulted advantageous effects included controlled release (Li et al., 2012), improved solubility (Wu et al., 2012), and equal or more efficient antimicrobial activity (Iannitelli et al., 2011).

As index of the physical properties of treated fillets, the $\mathrm{pH}$ of fillets coated with TLCNPs appeared within the range of fresh fillets recommended by ES 3494/ (2005) regulations till end of 4 days of refrigerated storage, (Table 8).

The findings of this study suggest the potential use of thymol for inactivation of $S$. Typhimurium in food. The newly developed technology in which thymol is encapsulated in chitosan nanodeliver represents a significant step in the direction of producing nanocapsules with prolonged antimicrobial activity. Such polymeric nanocapsules have the potential and efficiency in improving food safety.

\section{REFERENCES}

Abdou, E.S.; Osheba, A.S. and Sorour, M.A. (2012): Effect of chitosan and chitosan-nanoparticles as active coating on microbiological characteristics of fish fingers. International Journal Applied Science Technology, 2(7), 158169.[https://www.researchgate.net/pro file/Atef]

Ahmed, A.M. and Shimamoto, T. (2014): Isolation and molecular characterization of Salmonella enterica, Escherichia coli O157:H7 and Shigella spp. from meat and dairy products in Egypt. International Journal of Food Microbiology, 168169, 57-62. 
[https://doi.org/10.1016/j.ijfoodmicro. 2013.10.014]

Ahmed, A.M.; Shimamoto, T. and Shimamoto, $\quad$ T. (2014): Characterization of integrons and resistance genes in multidrug-resistant Salmonella enterica isolated from meat and dairy products in Egypt. International Journal of Food Microbiology, 189, 39-44. [https://doi.org/10.1016/j.ijfoodmicro. 2014.07.031]

Akhtar, S.; Ismail, T.; Fraternale, D. and Sestili, P. (2015): Pomegranate peel and peel extracts: chemistry and food features. Food Chemistry, 174, 417425.

[https://doi.org/10.1016/j.foodchem.2 014.11.035]

Alishahi, A. and Ä̈der, M. (2012): Applications of chitosan in the seafood industry and aquaculture: A review. Food Bioprocess Technology, 5 , 817-830. [https://doi.org/10.1007/s11947-0110664-x]

Alves, M.J.; Ferreira, I.C.F.R.; Froufe, H.J.C.; Abreu, R.M.V.; Martins, A. and Pintado, M. (2013): Antimicrobial activity of phenolic compounds identified in wild mushrooms, SAR analysis and docking studies. Journal of Applied Microbiology, 115(2), 346-357. [https://doi.org/10.1111/jam.12196]

Anvari, M.; Rezaei, M. and Kim, S.M. (2012): Effects of previous gutting on biochemical changes and profile of long-chain polyunsaturated fatty acids in cold-smoked kutum (Rutilusfrisii kutum) stored at room temperature $\left(25 \pm 2{ }^{0} \mathrm{C}\right)$. Journal of Food Biochemistry, 37, 742-747. [DOI: org/10.1111/j.1745-

4514.2012.00673.x].

Arikan, S. (2007): Current status of antifungal susceptibility testing methods. Medical Mycology, 45, 569587. [https://doi.org/10.1080/13693780701 436794]

Bakr, W.; El Sayed, A.; El Shamy, H. and Amine, A. (2013): Is it safe to eat raw seafood? Prevalence of Salmonella in some seafood products sold in Alexandria markets. Journal of Egypt Public Health Association, 88, 115120. [doi: 10.1097/01.EPX. 0000433559.22563.47]

Balouiri, M.; Sadiki, M. and Ibnsouda, S.K. (2016): Methods for in vitro evaluating antimicrobial activity: A review. Journal of Pharmaceutical Analysis, 6, 71-79. [https://doi.org/10.1016/j.jpha.2015.1 $1.005]$

Bhawana, Basniwal, R.K.; Buttar, H.S.; Jain, V.K. and Jain, N. (2011): Curcumin nanoparticles: preparation, characterization, and antimicrobial study. Journal of Agriculture and Food Chemistry, 59 (5), 2056- 61. [doi:10.1021/jf104402t.]

Cagri, A.; Ustunol, Z.; Osburn, W. and Ryser, E.T. (2003): Inhibition of Listeria monocytogenes on hot dogs using antimicrobial whey proteinbased edible casings. Journal of Food Science, 68 (1), 291-299. [https://doi.org/10.1111/j.13652621.2003.tb14155.x]

Campos, F.M.; Couto, J.A.; Figuereido, A.R.; Toth, I.V.; Rangel, A.O.S.S. and Hogg, T.A. (2009): Cell membrane damage induced by phenolic acids on wine lactic acids bacteria. International Journal of Food Microbiology, 135, 144- 151. [https://doi.org/10.1016/j.ijfoodmicro. 2009.07.031 ]

Chauhan, A.K. and Kang, S.C. (2014): Thymol disrupts the membrane integrity of Salmonella ser. Typhimurium in vitro and recovers infected macrophages from oxidative stress in an ex vivo model. Res. Microbiology, 165 (7), 559-65. [https://doi.org/10.1016/j.resmic.2014 $.07 .001]$ 
CIREPBN (Cosmetic Ingredient Review Expert Panel Bindu Nair) (2001): Final Report on the Safety Assessment of Benzyl Alcohol, Benzoic Acid, and Sodium Benzoate. International Journal of Toxicology, 20 (Suppl. 3), 23-50. [doi: 10.1080/10915810152630729].

CLSI "Clinical and Laboratory Standards Institute" (2012): Methods for dilution antimicrobial susceptibility tests for bacteria that grow aerobically. Approved Standard, 9th ed., CLSI document M07-A9. Clinical and Laboratory Standards Institute, 950 West Valley Road, Suite 2500, Wayne, Pennsylvania 19087, USA, 2012. [https://www.sciencedirect.com/scien ce/article/pii/S2095177915300150]

Collard, J.M.; Bertrand, S.; Dierick, K.; Godard, C.; Wildemauwe, C.; Vermeersch, K.; Duculot, J.; Van Immerseel, $\quad F$.; Pasmans, $F$.; Imberechts, H. and Quinet, C. (2008): Drastic decrease of Salmonella Enteritidis isolated from humans in Belgium in 2005, shift in phage types and influence on foodborne outbreaks. Epidemiol. Infect, 136, 771-781. [DOI: https://doi.org/ 10.1017/S095026880700920X]

Committee, F.W.E. (2001): Summary of evaluations performed by the joint FAO/WHO expert committee on food additives. Available at: [http://www.inchem.org/documents/je cfa/jeceval/jec_420.htm.]

Conte, R.; Calarco, A.; Napoletano, A.; Valentino, $A$. and Margarucci, $S$. (2016): Polyphenols nanoencapsulation for therapeutic applications. Journal of Biomol. Res. Ther, 5(2), 139. [http://dx.doi.org/ 10.4172/2167-7956.1000139]

Cuеva, C.; Moreno-Arribas, M.V.; Martinez-Alvarez, P.J.; Bills, G.; Vicente, M.F.; Basilio, A.; Lopez Rivas, C.; Requena, T.; Rodriguez, J.M. and Bartolome, B. (2010):
Antimicrobial activity of phenolic acids against commensal, probiotic and pathogenic bacteria. Res. Microbio,. 16, 372- 382. [https://doi.org/10.1016/j.resmic. 2010 .04.006 ]

De Reuck, K.; Sivakumar, D. and Korsten, L. (2009): Effect of integrated application of chitosan coating and modified atmosphere packaging on overall quality retention in litchi cultivars. Journal of Science, Food and Agriculture, 89 (5), 915- 920. [https://doi.org/10.1002/jsfa.3501]

Delgado, B.; Fernández, P.S.; Palop, A. and Periago, P.M. (2004): Effect of thymol and cymene on Bacillus cereus vegetative cells evaluated through the use of frequency distributions. Food Microbiology, 21 (3), 327-334. [https://doi.org/ 10.1016/S0740-0020(03)00075-3]

Devienne, K.F. and Raddi, M.S.G. (2002): Screening for antimicrobial activity of natural products using a microplate photometer. Brazilian Journal of Microbiology, 33 (2), 166-168. [https://doi.org/10.1590/S151783822002000200014]

EFSA and ECDC "European Food Safety Authority and European Centre for Disease Prevention and Control" (2018): The European Union summary report on trends and sources of zoonoses, zoonotic agents and food-borne outbreaks in the European Union in 2008. EFSA Journal, 8 (1), 1496. [https://doi.org/10.2903/j.efsa. 2018.5500]

Engels, C.; Knodler, M.; Zhao, Y.; Carle, $R$. and Schieber, A. (2009): Antimicrobial activity of gallotannins isolated from mango (Mangifera indica) kernels. Journal of Agriculture and Food Chemistry, 57 (17), 7712-7718. [https://doi.org/ $10.1021 / \mathrm{jf901621 \textrm {m } ]}$

Eom, S.H.; Santos, J.A.; Kim, J.H.; Jung, W.K.; Kim, D.H. and Kim, Y.M. (2015): In vitro antibacterial and 
synergistic activity of an Ecklonia cava extract against antibioticresistant Streptococcus parauberis. Fish. Aquat. Science, 18, 241-247. [https://doi.org/10.5657/FAS.2015.02 41]

ES 3494 "Egyptian Standards 3494" (2005): Chilled fish. Standards No. 3494, Egyptian Organization for Standardization and Quality Control. Ministry of Industry. Cairo, Arab Republic of Egypt. [http://www. alcpo.org.ly/wp-conte nt/uploa ds/2017/06/newfo odsta ndards.pdf]

EUCAST "European Committee for Antimicrobial Susceptibility Testing" (2003): Determination of minimum inhibitory concentrations (MICs) of antibacterial agents by broth dilution. EUCAST discussion document E. D is 5.1, Clin. Microbiol. Infec, 9, 1 [https://doi.org/10.1046/j.14690691.2003.00790.x]

Fernandez-Sainz, P.; Ocio, M.J. and Lagaron, J.M. (2010): Antibacterial chitosan-based blends with ethylenevinyl alcohol copolymer. Carbohydr Polym, 80, 874-884.[ https://doi. org/10.1016/j.carbpol.2009.12.046]

Fitzgerald, D.J.; Stratford, M.; Gasson, M. J.; Ueckert, J.; Bos, A. and Narbad, A. (2004): Mode of antimicrobial action of vanillin against Escherichia coli, Lactobacillus plantarum and Listeria innocua. Journal of Applied Microbiology, 97, 104-113. [https:// doi.org/10.1111/j.1365-

2672.2004.02275.x ]

Garsuch, V. and Breitkreutz, J. (2010): Comparative investigations on different polymers for the preparation of fast-dissolving oral films. Journal Pharm. Pharmacol, 62 (4), 539-545. [https://doi.org/10.1211/jpp.62.04.001 8.]

Ghaderi-Ghahfarokhi, M.; Barzegar, M.; Sahari, M.A.; Gavlighi, H.A. and Gardini, F. (2017): Chitosancinnamon essential oil nanoformulation: Application as a novel additive for controlled release and shelf life extension of beef patties. International Journal of Biological Macromolecules, 1-32. [https://doi.org/10.1016/j.ijbiomac.20 17.04.002]

Ghaderi-Ghahfarokhi, M.; Barzegar, M.; Sahari, M.A. and Azizi, M.H. (2016): Nanoencapsulation approach to improve antimicrobial and antioxidant activity of thyme essential oil in beef burgers during refrigerated storage. Food Bioprocess Technology, 9, 1187-1201. [https://doi.org/10.1007/ s11947-016-1708-z]

Gómez-García, M.; Sol, C.; de Nova, P.J.G.; Puyalto, M.; Mesas, L.; Puente, H.; Mencía-Ares, Ó.; Miranda, R.; Argüello, H.; Rubio, P. and Carvajal, A. (2019): Antimicrobial activity of a selection of organic acids, their salts and essential oils against swine enteropathogenic bacteria. Porc. Health Manag. 5, 32 [ https://doi.org/10.1186/s40813-0190139-4.]

Gould, L.H.; Walsh, K.A.; Vieira, A.R.; Herman, K.; Williams, I.T.; Hall, A.J. and Cole, D. (2013): Centers for Disease Control and Prevention. Surveillance for foodborne disease outbreaks-United States, 1998-2008. MMWR Surveill. Summ. 62,134.[https://stacks.cdc.gov/view/cdc/13 732/cdc_13732_DS1.pdf]

GSFA "General Standard for Food Additives" (2007): Online Food Additive Group Details: Benzoates (2006) Archived 26 September 2007 at the Wayback Machine. Joint FAO/WHO Food Standards Program me, Rome [https://agris.fao.org/agrissearch/search.do? recordID $=$ XF20160 73676]

Guevara, L.; Antolinos, V.; Palop, A. and Periago, P.M. (2015): Impact of moderate heat, carvacrol, and thymol treatments on the viability, injury, and stress response of Listeria 
monocytogenes. BioMed Res. Internat, Article ID 548930, 10 pages [http://dx.doi.org/10.1155/2015/5489 30.]

Gullon, B.; Pintado, M.E.; Perez-Alvarez, J.A. and Viuda-Martos, M. (2016): Assessment of polyphenolic profile and antibacterial activity of pomegranate peel (Punica granatum) flour obtained from co-product of juice extraction. Food Control, 59, 94-98.

[https://doi.org/10.1016/j.foodcont.20 15.05.025]

Gupta, A.; Kaur, C.D.; Saraf, S. and Saraf, S. (2016): $\quad$ Formulation, characterization and evaluation of ligand-conjugated biodegradable quercetin nanoparticles for active targeting. Artif. Cells Nanomed. Biotechnol, 44, 960-970. [https:// doi.org/10.3109/21691401.2015.1008 503]

Hintz, T.; Matthews, K.K. and Di, R. (2015): The use of plant antimicrobial compounds for food preservation. BioMed Res. Internat, Article ID 246264, 12 pages [ http://dx.doi. org/10.1155/2015/246264.]

HSDB "Hazardous Substances Data Bank" (1997): HSDB record for benzoic acid. Last revision date: 97/04/01.[ https://pubchem.ncbi.nlm.nih.gov/co mpound/243]

Hsiao, C.P. and Siebert, K.J. (1999): Modeling the inhibitory effects of organic acids on bacteria. International Journal of food microbial., 47, 189-201. [doi:10.1016/S0168-1605(99)000124]

Hyldgaard, M.; Mygind, T. and Meyer, R.L. (2012): Essential oils in food preservation: mode of action, synergies, and interactions with food matrix components. Front Microbiology, 3, 1-24. [https://doi.org/10.3389/fmicb.2012.0 0012]
Iannitelli, A.; Grande, R.; Stefano, A.; Giulio, M.; Sozio, P.; Bessa, L.; Laserra, S.; Paolini, C.; Protasi, F. and Cellini, L. (2011): Potential antibacterial activity of carvacrol loaded poly (DL-lactide-co-glycolide) (PLGA) nanoparticles against microbial biofilm. International Journal of Molecular Sciences. 12, 5039-5051.[doi:10.3390/ ijms12085039]

Jahromi, M.A.M.; Al-Musawi, S.; Pirestani, M.; Ramandi, M.F.; Ahmadi, K.; Rajayi, H.;Hassan, Z.M.; Kamali, M. and Mirnejad, R. (2014): Curcuminloaded chitosan tripolyphosphate nanoparticles as a safe, natural and effective antibiotic inhibits the infection of Staphylococcus aureus and Pseudomonas aeruginosa in vivo. Iran Journal of Biotechnology, 12 (3), 1-8.

[https://www.sid.ir/en/journal/ViewPa per.aspx id $=431596]$

Jayasena, D.D. and Jo, C. (2013): Essential oils as potential antimicrobial agents in meat and meat products: A review, Trends Food Science and Technology, 34 (2), 96-108. [https://doi.org/ 10.1016/j.tifs.2013.09.002]

Jorgensen, J.H. and Ferraro, M.J. (2009): Antimicrobial susceptibility testing: a review of general principles and contemporary practices. Clin. Infectious Diseases, 49, 1749-1755. [https://doi.org/10.1086/647952]

Juven, B.J.; Kanner, J.; Schved, F. and Weisslowicz, H. (1994): Factors that interact with the antibacterial action of thyme essential oil and its active constituents. Journal of Applied Bacteriology, 76 (6), 626-631. [https://doi.org/10.1111/j.13652672.1994.tb01661.x]

Kassem, I.; Helmy, Y.A.; Kashoma, I.P. and Rajashekara, G. (2016): The Emergence of Antibiotic Resistance on Poultry Farms; Burleigh Dodds Science Publishing: Sawston, UK, Volume 
[http://dx.doi.org/10.19103/AS.2016. 0010.05]

Kim, B.S.; Kim, C.S. and Lee, K.M. (2008): The intracellular uptake ability of chitosan-coated Poly (D, L-lactidecoglycolide) nanoparticles. Archives of Pharmacal. Res, 31 (8), 1050-1054. [https://doi.org/10.1007/s12272-0011267-5]

Kong, M.; Chen, X.G.; Xing, K. and Park, H.J. (2010): Antimicrobial properties of chitosan and mode of action: A state of the art review. International Journal of Food Microbiology, 144, 51-63.

[https://doi.org/10.1016/j.ijfoodmicro. 2010.09.012]

Lambert, R.J.W.; Skandamis, P.N.; Coote, P.J. and Nychas, G.J.E. (2001): A study of the minimum inhibitory concentration and mode of action of oregano essential oil, thymol and carvacrol. Journal of Applied Microbiology, 91, (3), 453-462. [https://doi.org/10.1046/j.13652672.2001.01428.x]

Lang, M.M.; Harris, L.J. and Beuchat, L.R. (2004a): Evaluation of inoculation method and inoculum drying time for their effects on survival and efficiency of recovery of Escherichia coli $\mathrm{O}_{157}: \mathrm{H}_{7}$, Salmonella, and Listeria monocytogenes inoculated on the surface of tomatoes. Journal of Food Protection, 67, 732- 741. [https://doi.org/10.4315/0362-028X67.4.732]

Lang, M.M.; Harris, L.J. and Beuchat, L.R. (2004b): Survival and recovery of Escherichia coli $\mathrm{O}_{157}: \mathrm{H}_{7}$, Salmonella, and Listeria monocytogenes on lettuce and parsley as affected by method of inoculation, time between inoculation and analysis, and treatment with chlorinated water. Journal of Food Protection, 67, 1092- 1103. [https://doi.org/10.4315/ 0362-028X-67.6.1092]

Lapidot, T.; Walker, M.D. and Kanner, J. (2002): Can apple antioxidants inhibit tumor cell proliferation? Generation of $\mathrm{H}_{2} \mathrm{O}_{2}$ during interaction of phenolic compounds with cell culture media. Journal of Agriculture and Food Chemistry, 50, 3156-3160. [https://doi.org/10.1021/jf011522g]

Li, K.; Yin, S.; Yang, X.; Tang, C. and Wei, Z. (2012): Fabrication and characterization of novel antimicrobial films derived from thymol loaded zein sodium caseinate (SC) nanoparticles. Journal of Agricultural and Food Chemistry. 60, 11592-11600.

[ttps://doi.org/10.1021/jf302752v]

Lindqvist, $R$. (2006): Estimation of Staphylococcus aureus growth parameters from turbidity data: Characterization of strain variation and comparison of methods. Applied Environmental Microbiology, 72 (7), 4862-4870. [DOI: 10.1128/ AEM.00251-06]

Liu, Y.; McKeever, L.C. and Malik, N.S.A. (2017): Assessment of the antimicrobial activity of olive leaf extract against foodborne bacterial pathogens. Front. Microbiol, 8 (113), 1-8. [doi: 10.3389/fmicb.2017.00113]

Llana-Ruiz-Cabello, M.; Pichardo, S.; Maisanaba, S.; Puerto, M.; Prieto, A.I.; Gutiérrez-Praena, D.; Jos, A. and Cameán, A.M. (2015): In vitro toxicological evaluation of essential oils and their main compounds used in active food packaging: a review. Food Chemistry and Toxicology, 81, 9-27. [https://doi.org/10.1016/ j.fct.2015.03.030.]

Lou, Z.; Wang, H.; Rao, S.; Sun, J.; Ma, C. and Li, J. (2012): p-Coumaric acid kills bacteria through dual damage mechanisms. Food Control, 25, 550554.

[https://doi.org/10.1016/j.foodcont.20 11.11.022]

Luck, E. and Jager, M. (1997): Benzoic acid. Antimicrobial food additives: Characteristics, uses and effects, 2nd Ed. (E. Luck and M. Jager, eds.) pp. 
174- 182, Springer, New York, NY. [https://www.google.com.eg/search?h $\mathrm{l}=\mathrm{ar} \& \mathrm{tbo}=\mathrm{p} \& \mathrm{tbm}=\mathrm{bks} \& \mathrm{q}=$ inauthor: $\%$ 22Erich+L\%C3\%BCck\%22]

Ma, Z.; Lim, T.M. and Lim, L.Y. (2005): Pharmacological activity of peroral chitosan-insulin nanoparticles in diabetic rats. International Journal of Pharm, 293 (1-2), 271-80. [doi:10.1016/j.ijpharm.2004.12.025.]

Mazumder, A.; Davis, J.; Rangari, V. and Curry, M. (2013): Synthesis, characterization and applications of dendrimer-encapsulated zero-valent $\mathrm{Ni}$ nanoparticles as antimicrobial agents. ISRN Nanomaterials. 843709, 9. [https://doi.org/10.1155/2013/ 843709]

McFarland, J. (1907): Nephelometer an instrument for estimating the number of bacteria in suspensions used for calculating the opsonic index and for vaccines. Journal of American Medical Association, 14, 1176-1178. [https://jamanetwork.com/journals/ja $\mathrm{ma} /$ article-abstract/444820]

Medina, E.; Caro, N.; Abugoch, L.; Gamboa, A.; Díaz-Dosque, M. and Tapia, C. (2019): Chitosan thymol nanoparticles improve the antimicrobial effect and the water vapour barrier of chitosan-quinoa protein films. Journal of Food Engineering, 240, 191-198. [https://doi.org/10.1016/j.jfoodeng.20 18.07.023.]

Meeran, M.F.N.; Javed, H.; Al Taee, H.; Azimullah, S. and Ojha, H.K. (2017): Pharmacological Properties and Molecular Mechanisms of Thymol: Prospects for its therapeutic potential and pharmaceutical development. Front. Pharmacology, https://doi.org/10.3389/fphar.2017.00 380]1

Menconi, A.; Pumford, N.R.; Morgan, M.J.; Bielke, L.R.; Kallapura, G.; Latorre, J.D.; Wolfenden, A.D.; HernandezVelasco, X.; Hargis, B.M. and Tellez, G. (2014): Effect of chitosan on
Salmonella Typhimurium in broiler chickens. Foodborne Pathogens and Disease, $11 \quad$ (2), 165-169. [https://www.liebertpub.com/doi/pdfp lus/10.1089/fpd.2013.1628]

Merkl, R.; Hrádková, I.; Filip, V. and Šmidrkal, J. (2010): Antimicrobial and antioxidant properties of phenolic acids alkyl esters. Czech Journal of Food Science, 28, 275- 279. [https://www.agriculturejournals.cz/p ublicFiles/132_2010-CJFS.pdf]

Mohan, C.O.; Ravishankar, C.N.; Lalitha, K.V. and Gopal, T.K.S. (2012): Effect of chitosan edible coating on the quality of double filleted Indian oil sardine (Sardinella longiceps) during chilled storage. Food Hydrocolloids. 26 167-174.

[http://dx.doi.org/10.1016/j.]

Mota, F.L.; Maria, E.R.M. and Pinho, S.P. (2010): Solubility studies with pharmaceutical applications. Faculdade Engenharia Universidade do Porto. [https://bibliotecadigital. ipb.pt/bitstream/10198/14601/1/Se\% CC\%81rgio.pdf]

Natta, L.; Orapin, K.; Krittika, N. and Pantip, B. (2008): Essential oil five Zingiberaceae for anti-food-borne bacteria. International Food Research Journal, 15, 337-346. [http://iapb.kiau.ac.ir/article_519562_ 028bdde3aa68068663d95745c69c3ff 5.pdf]

Nguyen, M.H. and Yu, C.Y. (1999): Influence of incubation time, inoculum size, and glucose concentrations on spectrophotometric endpoint determinations for amphotericin B, fluconazole, and itraconazole. Journal of Clinical Microbiology, 37 (1), 141-145. [https://jcm.asm.org/content/jcm/37/1 /141.full.pdf]

Olasupo, N.A.; Fitzgerald, D.J.; Gasson, M.J. and Narbad, A. (2003): Activity of natural antimicrobial compounds against Escherichia coli and Salmonella enterica serovar 
Typhimurium. Letters in Applied Microbiology, 37 (6), 448-451. [https://sfamjournals.onlinelibrary.wil ey.com/doi/full/10.1046/j.1472765X.2003.01427.x]

Pacheco-Ordaz, R.; Wall-Medrano, A.; Gon $i, \quad$ M.G.; Ramos-ClamontMontfort, G.; Ayala-Zavala, J.F. and Gonzalez-Aguilar, G.A. (2017): Effect of phenolic compounds on the growth of selected probiotic and pathogenic bacteria. Letters in Applied Microbiology, 66, 25-31. [doi: 10.1111/lam.12814.]

Pan, K.; Chen, H.Q.; Davidson, P.M. and Zhong, Q.X. (2014): Thymol nanoencapsulated by sodium caseinate: physical and antilisterial properties. Journal of Agriculture and Food Chemistry, 62 (7), 1649-1657. [https://doi.org/10.1021/jf4055402.]

Pisoschi, A.M.; Pop, A.; Georgescu, C.; Turcus, V.; Olah, N.K. and Mathe, E. (2017): An overview of natural antimicrobials role in food. Eur. J. Med. Chem., 143, 922-935. [https://www.sciencedirect.com/scien ce/article/pii/S0223523417309984]

Rai, D.; Singh, J.K.; Roy, N. and Panda, D. (2008): Curcumin inhibits FtsZ assembly: an attractive mechanism for its antibacterial activity. Biochem. Journal, $410 \quad$ (1), 147-55. [doi:10.1042/BJ20070891.]

Raj, V. and Prabha, G. (2016): Synthesis, characterization and in vitro drug release of cisplatin loaded Cassava starch acetate-PEG/ gelatin nanocomposites. Journal of Association of Arab Universities for Basic and Applied Science, 21, 1016. [https://www.sciencedirect.com/ science/article/pii/S18153852150002 79]

Ravichandran, M.; Hettiarachchy, N.S.; Ganesh, V.; Ricke, S.C. and Singh, S. (2011): Enhancement of antimicrobial activities of naturally occuring phenolic compounds by nanoscale delivery against Listeria monocytogenes, Escherichia coli $\mathrm{O}_{157}: \mathrm{H}_{7}$ and Salmonella Typhimurium in broth and chicken meat system. Journal of Food Safety, 31(4), 462-471. [https://doi.org/ 10.1111/j.1745-4565.2011.00322.x]

Redhead, H.M.; Davis, S.S. and Illum, L. (2001): Drug delivery in poly (lactide-co-glycolide) nanoparticles surface modified with poloxamer 407 and poloxamine 908: In vitro characterisation and in vivo evaluation. Journal of Controlled Release, 70, 353- 363. [https://www.sciencedirect.com/scien ce/article/pii/S0168365900003679]

Sallam, K.I. (2007): Chemical, sensory and shelf life evaluation of sliced salmon treated with salts of organic acids. Food Chemistry, 101(2), 592-600. [http://dx.doi.org/10.1016/j.foodchem 2006.02.019. PMid:17245440.]

Sánchez-Maldonado, A.F.; Schieber, A. and Gänzle, M.G. (2011): Structurefunction relationships of the antibacterial activity of phenolic acids and their metabolism by lactic acid bacteria. Journal of Applied Microbiol. Banner, 111(5), 11761184. [https://doi.org/10.1111/j.13652672.2011.05141.x.]

Sánchez-Ortega, I.; García-Almendárez, B.E.; Santos-López, E.M.; AmaroReyes, A.; Barboza-Corona, J.E. and Carlos Regalado, C. (2014): Antimicrobial edible films and coatings for meat and meat products preservation. Science World Journal, Article ID 248935, 1-18. [https://doi.org/10.1155/2014/248935 ]

Silva-Angulo, A.B.; Zanini, S.F.; Rosenthal, A.; Rodrigo, D.; Klein, G. and Martínez, A. (2015): Comparative study of the effects of citral on the growth and injury of Listeria innocua and Listeria monocytogenes Cells. PLoS ONE 10: e0114026. [doi:10.1371/journal.pone.0114026] 
Singh, R.K.; Rai, D.; Yadav, D.; Bhargava, A.; Balzarini, J. and De Clercq, E. (2010): Synthesis, antibacterial and antiviral properties of curcumin bioconjugates bearing dipeptide, fatty acids and folic acid. Eur. Journal Med. Chem, 45(3), 1078-86. [doi:10.1016/j.ejmech.2009.12.002.]

Soto-Chilaca, G.A.; Ramírez-Corona, N.; Palou, E. and López-Malo, A. (2016): Food antimicrobial agents using phenolic compounds, chitosan, and related nanoparticles. Journal of Food Bioengineering and Nanoprocessing, l(2), $165-181 . \quad$ [http://www. nanobiofoods.com/]

SPSS "Sample power Statistic Software" (2007): Sample power Statistic, SPSS, 12.01Syntax Reference Guide for SPSS Base. SPSS Inc, 233 South Wacker Drive, Chicago, IL.pp111119.

Tarabees, R.; Elsayed, M.S.A.; Shawish, R.; Basiouni, S. and Shehata, A.A. (2017): Isolation and characterization of Salmonella Enteritidis and Salmonella Typhimurium from chicken meat in Egypt. J. Infect. Dev. Ctries. 11, 314-319.[doi: 10.3855/jidc.8043]

USFDA "United States Food and Drug Administration" (2014): U.S.
National Archives and Records Administration's Electronic Code of Federal Regulations. 21 CFR 172.515. Available from, [http://www.ecfr.gov.]

Vashisth, P.R.P., Singh and Pruthi, A. (2015): Controlled release system for quercetin from biodegradable poly (lactide-co-glycolide)-

polycaprolactone nanofibers and its in vitro antitumor activity. Journal of Bioact. Compat. Pol., 31(3), 260-272. [https://journals.sagepub.com/doi/abs/ 10.1177/0883911515613098]

Venugopala, K.N.; Rashmi, V. and Odhav, B. (2013): Review on natural coumarin lead compounds for their pharmacological activity. BioMed Res. International, Article ID 963248, 14 pages. [https://doi.org/10.1155/ 2013/963248 ]

Wu, Y.; Luo, Y. and Wang, Q. (2012): Antioxidant and antimicrobial properties of essential oils encapsulated in zein nanoparticles prepared by liquid-liquid dispersion method. Food Science and Technology. 48, 283-290. [ https://doi.org/10.1016/j.lwt.2012.03. 027]

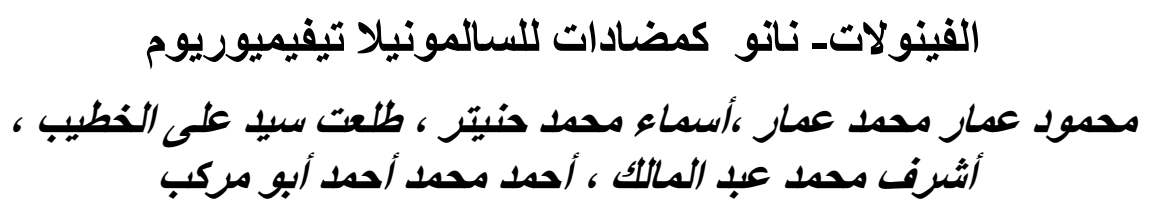

E-mail: mahmoud2014eg@yahoo.com Assiut University web-site: www.aun.edu.eg

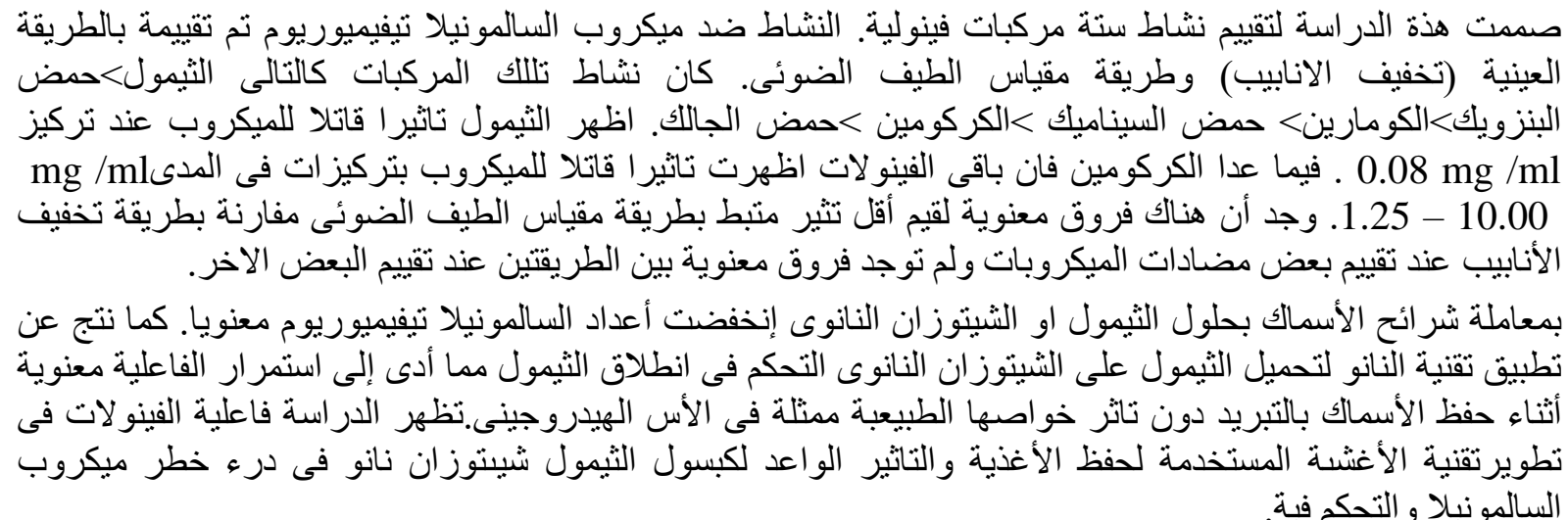

